\title{
The Effect of Information Technology Mastery and Job Motivation on the Productivity of Elementary School Teachers in the Semidang Aji District
}

\author{
Armawati ${ }^{1 *}$, Syarwani Ahmad $^{2}$, Destiniar ${ }^{2}$ \\ ${ }^{1}$ SD Negeri 97 OKU Desa Singapura, South of Sumatera, Indonesia \\ ${ }^{2}$ Universitas PGRI Palembang, Indonesia \\ *Corresponding author. Email: armawati9703@gmail.com
}

\begin{abstract}
The aim of this study is to identify and describe: 1) the effect of mastery of information technology on teacher performance; 2) the effect of mastery of job motivation on teacher quality; and 3) the effect of mastery of information technology and job motivation on the performance of Elementary School teachers in Semidang Aji District. The analysis approach is descriptive quantitative. The population are 102 teachers. The data collection techniques use some questionnaires and documentation. Simple linear and multiple linear regression formulas are used to evaluate data. The findings revealed: 1) mastery of information technology has a significant effect on teacher performance; 2) work motivation has a significant effect on teacher performance; and 3) mastery of information technology and work motivation have a significant impact on the performance of Elementary School teachers in Semidang Aji District. The effect of information technology mastery and job motivation on the performance of elementary school teachers in the Semidang Aji District is 26.1\%; the remaining $73.9 \%$ is affected by other factors not included in the variables in this study.
\end{abstract}

Keywords: Technology of Information, Work Motivation, Teacher Performance

\section{INTRODUCTION}

The rapid advancement of information and communication technology has resulted in numerous changes in various fields of life, including education. Education has a very important role in human life. Along with advances in science and technology, skilled educators capable of carrying out their responsibilities as educators, instructors, mentors and trainers of the nation's children in the future are needed who can provide active, creative, innovative learning directions and high interest in students [1]

The existence of globalization that has become increasingly prevalent lately has resulted in increasingly unstoppable technological developments. Globalization is a condition in which interactions between nations increasingly show interdependence and openness. With globalization, the spread of developing technology has become easier to spread throughout the world [2]. The situation that happens in the eastern hemisphere can easily be accessed by people in the western hemisphere, and the situation that happens in the western hemisphere can immediately be accessed by people in the eastern hemisphere.
The development of information and communication technology from time to time is increasingly being used in various fields and aspects of life. In fact, it is undeniable that today almost every aspect of our life is related to technology. This is done to provide convenience and create human efficiency in completing their work. Education is one example of an area that has gained greatly from the advancement of science and technology. The application of information and communication technology in the field of education is extremely valuable for both educational purposes, as well as for school administration management.

The development of information technology has entered various aspects of life, including the world of education, more specifically, learning has been intervened by the existence of this technology. Together with the advancement of information technologies in education, various learning materials have been produced and consumed by learners through the medium of information technology in very varied forms of packaging. It is different from the traditional learning process which relies on the teacher as the first and foremost learning source, while other sources are only complementary to learning activities [3]. 
So far, he has known and even used several forms of educational technology to assist learning activities. Some of these tools include OHP, LCD, Projector, computer, and some laboratory equipment. The emergency of tools in educational technology brings new nuances, especially when it comes to the knowledge construction process. The public response of the users of educational technology is very large, so that in the future this technology has become so familiar in helping the smooth implementation of education and learning.

The highest development of technological, especially communication technology, have brought about major changes in various fields. One of the fields that is also developing as a result of advances in communication technology is the field of education and learning. If in previous times the relationship between educators and students only took place through face-toface activities, limited by space and time barriers, or through media, nowadays it can be developed through online communication that penetrates the barriers of time and space. Through this electronic media, in addition to many added values or say "advantages" or advantages, from the pedagogical dimension, of course there are many factors that deserve attention, for example how the shift in educational communication patterns between teachers and students, how about motivational learning techniques, how about the understanding of students, and several other aspects of learning psychology [4].

The revolution in science and technology, changes in people's understanding of children's learning methods, advances in communication media and so on, give their own meaning to educational activities and this demand has made policies to utilize technological media and technological approaches in the management of education. Education as part of culture is a means of passing on values, ideas, so that everyone is able to participate in the transformation of values for the progress of the nation and state. This means that education is a place where science and technology are transformed for the good of human life. In the context of teaching and learning activities, the use of communications technologies, educational technology, and educational material is needed. Since the aims of effective and efficient education would be fulfilled with a scientific, systematic, and logical approach, as required by this educational technology [5].

In a broader context, ICT (Information and Communication Technology) encapsulates all aspects related to machines (computers and telecommunications) and the techniques used to capture (collect), store, manipulate, and deliver. Computers that control all forms of ideas and information play an important role. Collecting, processing, storing and disseminating voice information, images, text and numbers by combined computing and telecommunications which are microelectronics. Information and communication technology combines the field of technology in computing. Telecommunications and electronics and information fields such as data, facts and processes [6].

Thus, it can be said that the existence of information technology can facilitate the process of transferring an idea and equalizing perceptions. to incorporate technology into different areas of life, including learning. Learning program was aimed at preparing human capital to face global challenges by using information and communication technologies. By utilizing the development of information and communication technology, education can reach all levels of society who live in various places, in cities, villages, even in remote or inland areas. One of the educational institutions is a school. School is a forum for creating educated people regardless of the background of these students. Schools are expected to be able to create optimal output, namely Human Resources (HR) who are able to compete in the global world. To make it happen, the introduction of learning makes use of ICT, because technological progress is accelerating in the international world.

The application of ICT in education is one of the factors in solving three strategic issues of national education, namely: expanding and equitable access, improving quality and relevance, and good governance and accountability, considering that the current era of globalization requires the utilization of ICT, as the most effective and efficient means of catching up with education backwardness. So that the focus of handling educational objects is focused on improving human resources and infrastructure, including the following: supporting the 9-year-old Basic Education and the pioneering of 12-year-old Secondary Education through a distance learning system, supporting the improvement of the quality of primary and secondary education through the use of ICT, and support learning enrichment through the operation and use of ICT and E-Learning [7].

Learning occurs when there is an interaction between educators and students. Developing information and communication technology in learning, at least educators are able to master and want to use technology. In Permen 16/2007 concerning Academic Qualification Standards and Teacher Competencies, in the section on Pedagogic Competencies for High School Teachers, it is said that the competence of subject teachers is to incorporate ICT into classroom instruction. This means that learning is no longer conventional. Teachers are required to actually to use ICT in educational, as well as use a range of methodologies, tactics, processes, and learning techniques to engage students creatively in the subjects they teach. In practice, however, not all teachers understand and use information and communication technology in the education process. Whereas use of ICT in education is dependent on teachers' skill and innovation in using it. In addition, students must also be 
able to master technology so that there is reciprocity between teachers as educators and students.

Teachers and students may be using information technology to help them locate information or learning materials, close space and time gaps in teacher-student interactions, improve learning performance, and store different data and information. Information technology is able to make concrete abstract concepts (difficult to imagine); display objects that are too large; displays objects that cannot be seen with the naked eye; observing movements that are too fast, for example by slow motion or time-lapse photography; enables students to engage directly with their environment; ensures consistency of impressions and perceptions for student learning experiences; generates student learning motivation; and regularly presents learning knowledge, accurately, of quality and can be repeated or stored as needed; or presenting messages or learning information simultaneously for a small / large or large / wide scope of objectives, overcoming time constraints (anytime) or space (anywhere). In other words, ICT has the potential to improve learning efficiency and learning quality. ICT can generate educate motivation.

The use of IT is expected to increase the success of the teaching and learning process and teacher performance. States that the application of appropriate information and communication technology applications is one of the most significant main factors in the field of education is to enhance the quality of education and human capital. The use and advancement of ICT more than just a response to global trends; it is a strategic step in the effort to increase educational access and efficiency. This is also one of the key factors to catch up with the world of education and the quality of Indonesia's human resources with other nations [8].

The teacher is a critical component of the teaching method, particularly in schools. The role of teachers is very important in transforming educational inputs, so that it can be ensured that in schools there will be no change or improvement in quality without changes and improvements in teacher quality. This shows that positive and excellent learning would continue to be dependent on the standard of teachers' working conditions. According to UNESCO, "improving the standard of education is primarily dependent on improving teacher recruitment, preparation, social status, and conditions; they need knowledge and skills, personal character, career opportunities, and the right motivation if they are to fulfill customer requirements" [9].

The teacher as an element in the teaching and learning process has multiple roles, not only as a teacher who transfers of knowledge, but also as a guide who encourages the potential of students to develop alternatives in learning. This means that teachers have complex duties and responsibilities towards achieving educational goals, where teachers are not only required to master the knowledge to be taught and have a set of teaching technical knowledge and skills, but are also required to display a personality that is capable of being role models for students. For this reason, teachers are required to optimize their performance in carrying out their duties.

Which states that "performance (performance) is a certain requirement which in the end can be directly reflected in the production generated in terms of both quantity and quality. The result could be in the form of physical or non-physical which states that it is a work" [10]. A teacher in doing his job well, is often determined by an assessment of his performance. Assessment is not only carried out to help monitor resources but to measure the efficiency level of using existing resources and identify things that need to be improved. Assessment of work performance is a critical factor in enhancing teacher success and job satisfaction. The parts that indicate the teacher's inadequate ability can be identified, so that strategies can be determined to improve performance.

Teacher success is the outcome of a teacher's work in carrying out tasks assigned to him based on his abilities, expertise, severity, and time [11]. Teacher success can be measured by their sense of duty and carrying out another mandate, the role they hold, and the moral responsibility they bear. Much of this would be evident in their discipline and commitment to their teacher roles in the classroom as well as their educational responsibilities outside of the classroom. This mindset will be followed by a sense of duty in planning all teaching materials before beginning the learning process. In addition, teachers have also considered the methodology to be used, including the educational media tools to be used, as well as what assessment tools will be used in the evaluation.

In general, two factors influence a teacher's performance: self-related factors and environmental factors. Which includes self-factors that affect teacher performance are motivation, ability, teacher conditions at work including: the teacher's ability to teach, teacher skills in explaining material and personal or educational background or teaching experience. Environmental factors that affect a teacher's performance are physical environmental conditions including: facilities and infrastructure, co-workers.

Job motivation is one of the factors that affect teacher performance. Work motivation is an important factor that drives an individual to perform specific tasks in order to achieve an objective [12]. Therefore, work motivation in psychology is a booster for morale. The desire to educate drives the teacher to become an educator. You will not be able to educate or teach if you are not motivated. Teachers who are motivated to work will encourage to improve their performance.

Motivation is the things that cause, unite, and pay attention to certain behaviors. Work motivation has been one of the variables that impact a teacher's success. The magnitude of motivation's effect on teacher success 
is determined at just how much motivation is affected by internally and externally parameters [13]. Work motivation as something that creates a boost or morale or in other words a booster of morale. Motivation has characteristics that cannot be separated from human nature itself, where humans individually have different qualities of self. Motivation becomes the actualization of a teacher to improve their performance.

Initial observations were made by interviewing teachers to find out problems at the elementary school level in the Semidang Aji sub-district. From the results of interviews with several teachers, there were still some problems in the field, including: (1). lesson planning has not been made optimally, (2). teachers have not used various media and varied learning sources; (4). The use of information technology has not been maximally used in learning, (5). Teachers' work motivation is still in the low category, teachers only carry out their duties but not totally in their profession as teachers

\section{METHODS}

This analysis employs the quantitative descriptive approach, which means that the knowledge collected is interpreted numerically and statistically, with the type of correlational research. The aim of this analysis is to determine the relationship between one variable and another [14]. Correlation study is an example of expostfacto research since researchers typically do not manipulate the state of existing variables and instead look for the nature and degree of relationship between variables as expressed in the Sukardi correlation coefficient [15]. Ex post facto analysis does not regulate variables and usually does not have a pre-test [16]. The ex post facto research design is a research that aims to investigate the events that have occurred and then trace back to find out the factors that caused these events. The following are the data collection techniques used in this study: 1) Observation, 2) Documentation, and 3) Questionnaire.

\section{RESULTS AND DISCUSSION}

\section{1) The Effect of Information Technology Mastery on Teacher Productivity}

More information on the effects of this testing hypotheses can be found in the table below:

\section{Table 1. Significance of the Effect of Information Technology Mastery} on Teacher Productivity

Coefficients $^{\mathrm{a}}$

\begin{tabular}{|c|c|c|c|c|c|}
\hline \multirow[b]{2}{*}{ Model } & \multicolumn{2}{|c|}{ Unstandardized Coefficients } & \multirow{2}{*}{$\begin{array}{c}\text { Standardized } \\
\text { Coefficients }\end{array}$} & \multirow[b]{2}{*}{$\mathrm{t}$} & \multirow[b]{2}{*}{ Sig. } \\
\hline & B & Std. Error & & & \\
\hline $1 \quad$ (Constant) & 45.142 & 14.801 & & 3.050 & .003 \\
\hline $\begin{array}{l}\text { Information } \\
\text { Technology }\end{array}$ & .616 & .190 & .309 & 3.247 & .002 \\
\hline
\end{tabular}

a. Dependent Variable: Teacher Productivity

Based on the analysis, the following basic regression model is solved: $\hat{\mathrm{Y}}=45.142+0.616 \mathrm{X} 1$, in connection with the results of the simple linear regression equation, it can be interpreted as follows: a) If mastery of information technology is zero, teacher performance will be constant at 45.142 .

b) Mastery of IT has a positive effect on teacher performance will be constant of 0.616 if other variables are considered constant.

This means the educator quality is affected positively by mastery of information technology with a coefficient value of 0.616 . Or in other words, teacher performance will increase if supported by good mastery of information technology. Furthermore, the chance value (0.000) is less than the value (0.164). The t table value is 1.686 as a consequence of the above interpolation calculations. As a result, the value of $t$ (3.247) is higher than the benefit of t table (1.686), implying that $\mathrm{Ha}$ is approved. That is, mastery of information technology has an impact on teacher efficiency.

Thus, mastery of information technology is needed to improve teacher performance. The study's findings suggest that mastery of information technology and job motivation have a positive and important effect on teacher efficiency. (3.247) is greater than t table (1.686), indicating that $\mathrm{Ha}$ is approved. That is, mastery of information technology has an impact on teacher efficiency. The effect of information technology 
mastery on teacher success is $0.95 \%$; the additional $99.05 \%$ is determined by non-variable factors.

Based on the above, it is possible to infer that the higher the mastery of information technology, the greater the lecturer's efficiency, and conversely, the lower the mastery of information technology, the lower the teacher's efficiency.

\section{2) The Effect of Work Motivation on Teacher Productivity}

More information on the effects of this testing hypotheses could be found in table below.

\section{Table 2. Significance of the Effect of Work Motivation on Teacher Productivity}

Coefficients $^{\mathrm{a}}$

\begin{tabular}{|c|c|c|c|c|c|}
\hline \multirow[b]{2}{*}{ Model } & \multicolumn{2}{|c|}{$\begin{array}{l}\text { Unstandardized } \\
\text { Coefficients }\end{array}$} & $\begin{array}{l}\text { Standardized } \\
\text { Coefficients }\end{array}$ & $\mathrm{t}$ & Sig. \\
\hline & B & Std. Error & Beta & & \\
\hline $1 \quad$ (Constant) & 37.816 & 10.721 & & 3.527 & .001 \\
\hline $\begin{array}{l}\text { Work } \\
\text { motivation }\end{array}$ & .605 & .117 & .460 & 5.179 & .000 \\
\hline
\end{tabular}

The results of hypothesis testing obtained a

Depend on the calculations, the following basic regression analysis equation is obtained: In relation to the effects of the simple regression formula, $Y=37.816$ $+0.605 \mathrm{X} 2$ can be interpreted as follows: a) If work motivation is zero, the teacher's performance will be constant at 37.816 . b) Workplace motivation improves teacher efficiency by 0.605 if other variables are considered constant.

This means that job encouragement has a positive impact on teacher success with a coefficient value of 0.605 . Or in other words, work motivation will provide an increase in teacher performance. In addition, the chance $(0.000)$ value is less than the value $(0.05)$. The $t$ table value is 1.686 as a consequence of the above interpolation calculations. As a result of the fact that the value of $t$ (5.179) is higher than the value of the table (1.686), it can be inferred that $\mathrm{Ha}$ is approved. This means that job encouragement has an impact on teacher efficiency.

Motivation to work in improving teacher performance is very important to know because it involves career advancement for educators / teachers. Job analysis is basically a tool for organizational leaders in solving employment problems humanely. According to Susilo, job analysis can provide benefits in many ways, including: (1) In the recruitment, selection and placement of workers, (2) In education, (3) In job appraisal, (4) In improving job conditions, (5) In organizational planning, (6) and in education and promotion. probability value $(0.000)$ which is smaller than the value of $\alpha(0.05)$, in addition, for the value of tcount (5.179) is greater than table (1.686) so it can be concluded that Ha is accepted. That is, there is a significant effect of work motivation on teacher performance. The amount of influence of work motivation on teacher performance is $21.1 \%$, the remaining $78.9 \%$ is influenced by other factors which are not variables in this study.

Based on the description above, it can be concluded that the better the work motivation, the better the teacher's performance and, the lower the work motivation, the lower the teacher's performance.

\section{3) The Effect of Information Technology Mastery and Work Motivation on Productivity}

The following are the results of the multiple regression test which are presented in the table below: 
Table 3. Significance of Information Technology Mastery and Work Motivation on Productivity

Coefficients $^{\mathrm{a}}$

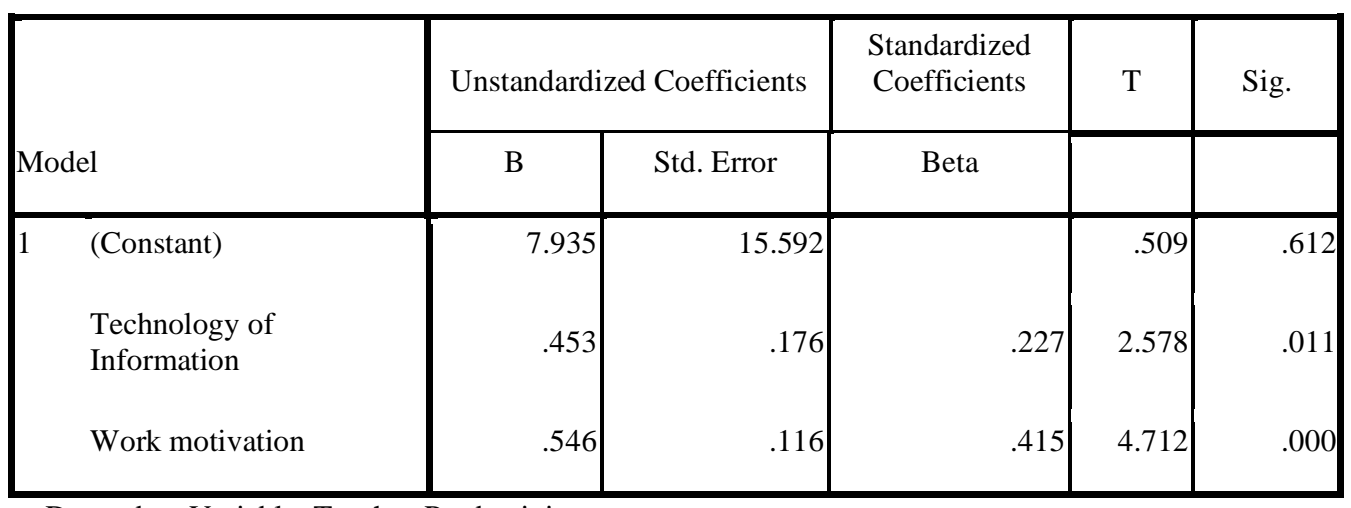

a. Dependent Variable: Teacher Productivity

This means that mastery of information technology and work motivation are important factors in improving teacher performance.

The results show that there is a positive and significant relationship between mastery of information technology and work motivation with teacher performance, this is evidenced by the value of the hypothesis testing results obtained by the probability value $(0.000)$ is smaller than the value of $\alpha(0.05)$, in addition, for the value Fcount of 17.492 is greater than $F$ (0.05) (1:53) of 4.02 so that Ha is accepted. This means that there is a significant influence between mastery of information technology and work motivation on teacher performance.

Based on the analysis, the following basic linear regression equation is obtained. $\mathrm{Y}=7935+0.453+$ $0.546 \mathrm{X} 2$. This could be represented in relation to the results of the simple linear regression equation as follows: 1) If the mastery of information technology and work motivation is zero, the teacher's performance will be constant (a) of 7,935. 2) Mastery of information technology has a positive effect on teacher performance by 0.453 if other variables are considered constant. 3) Work motivation has a positive effect on teacher performance by 0.546 if other variables are considered constant.

The effect of mastery of information technology and work motivation on teacher performance is $26.1 \%$, the remaining $73.1 \%$ is influenced by other factors that are not included in the variables in the research.

Many factors affect teacher performance, including mastery of information technology and work motivation, which are essentially the result of the interaction between these various factors, including mastery of information technology and work motivation and teacher performance, where the results of this study also show that mastery of information technology and work motivation provide an effective contribution of $26.1 \%$ on teacher performance.

Thus, mastery of information technology and work motivation jointly influence teacher performance. The better the mastery of information technology and work motivation, the better the teacher's performance.

\section{CONCLUSION}

Based on the results of the research and discussion, it can be concluded as follows: 1) Mastery of information technology has a significant effect on teacher performance, 2) Work motivation has a significant effect on teacher performance, 3) Mastery of information technology and work motivation together have a significant effect on teacher performance.

\section{ACKNOWLEDGMENT}

Our deepest gratitude goes to Teachers in SD Negeri 97 OKU Desa Singapura, Chancellor of Palembang PGRI University, Director of the Postgraduate Program of PGRI Palembang University and the Education Management Study Program of PGRI Palembang University, who have supported us in doing this extraordinary thing. This project is funded independently. We also want to thank our Education Management friends who helped us a lot in a short time frame to complete this project.

\section{REFERENCES}

[1] Siagian. (2013). Manajemen Sumber Daya Manusia [Human Resource Management]. Jakarta: Bumi aksara. 
[2] Zamroni. (2007). Pendidikan dan Demokrasi dalam Transisi (Prakondisi menuju Era Globalisasi) [Education and Democracy in Transition (Preconditions to the Era of Globalization)]. Jakarta: PSAP Muhammadiyah.

[3] Saud, U. S. (2008). Inovasi pendidikan [Educational innovation]. Bandung: Alfabeta.

[4] Annurahman. (2009). Belajar dan Pembelajaran [Learning and Learning]. Bandung: Alfabeta.

[5] Danim, S. (2003). Media Komunikasi Pendidikan [Educational Communication]. Jakarta: Bumi Aksara.

[6] Munir. (2009). Pembelajaran Jarak Jauh Berbasis Teknologi Informasi Dan Komunikasi [Distance Learning Based on Information and Communication Technology]. Bandung: Alfabeta.

[7] Rusman. (2013). Belajar dan Pembelajaran Berbasis Komputer Mengembangkan. Profesionalisme Guru Abad 21 [Developing Computer Based Learning and Learning. 21st Century Teacher Professionalism]. Bandung: ALFABETA.

[8] Munir. (2009). Pembelajaran Jarak Jauh Berbasis Teknologi Informasi Dan Komunikasi Distance Learning Based on Information and Communication Technology]. Bandung: Alfabeta.

[9] Delors, J. (1996). Learning: The treasure within. Report to UNESCO of the international Commission on Education for the Twenty-first Century: Printed. Vendome: Presses Universitaires de France.

[10] Simamora, H. (2006). Manajemen Sumber Daya Manusia, Edisi 2 [Human Resource Management, 2nd Edition]. Yogyakarta: STIE YKPN.

[11] Hasibuan, M. (2005). Manajemen SDM. Edisi Revisi, Cetakan Ke Tujuh [HR Management. Revised Edition, Seventh Printing]. Jakarta: Bumi Aksara.

[12] Sardiman. (2011). Interaksi dan Motivasi Belajar Mengajar [Interaction and Teaching and Learning Motivation]. Jakarta: PT Rajagrafindo: Jakarta

[13] Uno, H. B. (2017). Teori Motivasi Dan Pengukurannya (Analisis di bidang pendidikan) [Motivation Theory and Its Measurement (Analysis in the field of education)]. Jakarta: Bumi Aksara.

[14] Sugiyono. (2016). Metode Penelitian Kuantitatif Kualitatif Qualitative Quantitative Research Methods]. Bandung: Alfabeta.

[15] Sukardi. (2008). Metodologi Penelitian Pendidikan, Kompetensi dan Praktiknya [Educational Research Methodology, Competence and Practice]. Jakarta: Bumi Aksara.
[16] Sukmadinata, N. S. (2012). Metode Penelitian Pendidikan [Educational Research Methods]. Bandung: Rosdakarya. 